\title{
POJĘCIE ZASAD PRAWA W ŚWIETLE IDEI POJĘĆ CO DO ISTOTY KWESTIONOWANYCH
}

\section{WPROWADZENIE}

Pojęcie zasad prawa jest od drugiej połowy XX w. ${ }^{1}$ jednym z żywiej dyskutowanych w teorii prawa; stanowi również jedno z częściej wykorzystywanych w języku prawniczym. Występuje duża różnorodność sposobów posługiwania się nim, co miało i nadal ma swój wpływ na ustalenia teoretyków (szczególnie w dogmatyce prawa konstytucyjnego) ${ }^{2}$. W płaszczyźnie językowej sprecyzowania dokonali Sławomira Wronkowska, Maciej Zieliński i Zygmunt

\footnotetext{
${ }^{1}$ G. Maroń (Zasady prawa. Pojmowanie $i$ typologia a rola $w$ wyktadni prawa $i$ orzecznictwie konstytucyjnym, Poznań 2011, s. 13) wskazuje, że w teorii światowej początkiem dyskusji na temat „zasad prawa” była praca J. Essera, Grundsatz und Norm in der Richterlichen Fortbildung des Privatrechts”, Tübingen 1956. Tę samą cezurę wskazują np. M. Atienza, J. Ruiz Manero (A Theory of Legal Principles, Dordrecht 1998, s. 3-4) i R. Alexy (On the structure of legal principles, „Ratio Juris” 2000, nr 3, s. 294). Istotnym punktem jej rozwoju było opublikowanie przez R. Dworkina artykułu The model of rules (,The University of Chicago Law Review” 1, 1967, s. 1446), przedrukowanego później jako rozdział I książki Biorac prawa poważnie, tłum. T. Kowalski, Warszawa 1998. Można w tym miejscu wskazać jednak za M. Bódigiem (Rules, Principles and the Problem of the Limits of Legal Reasoning, s. 12, https://ssrn.com/abstract=1318638 [dostęp: 24.02.2017]) pracę J. Dickinsona, który w 1929 r., definiując „ogólne zasady prawa”, pisał o tym, że zasady to wyrazy chronionych prawem interesów człowieka wchodzące w konflikty, dlatego też w stosowaniu wymagają wyważania, którego kompromisowy efekt stanowią reguły, a także że „mają istotny zwyczaj podróżowania w przeciwstawnych parach” (The law behind law: II, „Columbia Law Review” 3, 1929, s. 298-299). Historię dyskusji polskiej opisał m.in. S. Tkacz (O zintegrowanej koncepcji zasad prawa $w$ polskim prawoznawstwie: od dogmatyki do teorii, Toruń 2014, s. 23-64), oraz O. Bogucki i M. Zieliński (Zasady prawa z perspektywy ogólnej teorii prawa, w: P. Hofmański (red.), System prawa karnego, t. 3: Zasady procesu karnego, cz. 1, red. P. Wiliński, Warszawa 2014, s. 46-80).

${ }^{2}$ S. Tkacz, op. cit., s. 183, 205 i 231. Autor, aktualizując badania S. Wronkowskiej, M. Zielińskiego i Z. Ziembińskiego, Zasady prawa. Zagadnienia podstawowe, Warszawa 1974, wskazał, że w języku powszechnym słowo „zasada” jest właściwie wszechobecne (idem, op. cit., s. 74-75), w języku prawnym występuje w jedenastu znaczeniach (S. Tkacz, s. 115-118 i 179-180) i posługujacc się określeniem B. M. Ćwiertniaka - zwraca uwagę na występujące tam zjawisko „inflacji zasad” (ibidem, s. 240), terminologię orzecznictwa różnych poziomów w zakresie zasad cechuje zaś wręcz dowolność i przypadkowość (ibidem, s. 185, 218-219 i 230-231). Podobnie M. Atienza i J. Ruiz Manero wskazują, że hiszpańscy teoretycy prawa wyróżniają 11 znaczeń (eidem, op. cit., s. 5), a M. Kordela dopatrzyła się ich 13 (eadem, Zasady prawa. Studium teoretycznoprawne, Poznań 2012, s. 177-202).
} 
Ziembiński ${ }^{3}$, odróżniając „zasady w znaczeniu opisowym” (oznaczające pewną ideę, wzorzec ukształtowania instytucji prawnej) od „zasad w znaczeniu dyrektywalnym" (norm prawa obowiązującego) ${ }^{4}$. Klaryfikacja ta przyjęła się w dyscyplinach szczegółowych, jednak nie na tyle wyraźnie, aby powstrzymać M. Zielińskiego od wyrażenia stanowiska, że problematykę zasad spowija nadal „chaos terminologiczny”.

Zagadnienie treści teoretycznej zasad, mimo bogatego opracowania w teorii polskiej i światowej, czeka wciąż na podobne wyjaśnienie. Wśród badaczy, którzy przyjmują ich istnienie jako norm o odmiennych od pozostałych właściwościach, trwa dyskusja co do tego, jak dokładnie ich zbiór się przedstawia oraz jaki ma charakter ${ }^{6}$. W teorii rodzimej do niedawna istniały dwa główne stanowiska w tej materii. Pierwsze za Maciejem Zielińskim i Olgierdem Boguckim nazwać można „polska koncepcja zasad prawa”; jego zwolennicy hołdują ustaleniom Jerzego Wróblewskiego ${ }^{8}$ oraz wspomnianych Sławomiry Wronkowskiej, Maciej Zielińskiego i Zygmunta Ziembińskiego9. Przedstawiciele drugiego odwołuja się, od czasu przedstawienia ich założeń przez Wiesława Langa i Jerzego Wróblewskiego ${ }^{10}$ oraz Tomasza Gizberta-Studnickiego ${ }^{11}$, do koncepcji Ronalda Dworkina ${ }^{12}$ i Roberta Alexy'ego ${ }^{13}$, które choć częściowo daja się pogodzić z koncepcja polska, w wielu fragmentach prowadzą do diametralnie różnych ustalen ${ }^{14}$. To rozległe spektrum poglądów wzbogaciły ostat-

${ }^{3}$ S. Wronkowska, M. Zieliński, Z. Ziembiński, op. cit.

${ }^{4}$ Ibidem, s. 24-27.

${ }^{5}$ M. Zieliński, Zasady i wartości konstytucyjne, w: A. Bałaban, P. Mijal (red.), Zasady naczelne Konstytucji RP z 2 kwietnia 1997 roku, Szczecin 2011, s. 21. Wypowiedź tę przywołuja afirmująco niektórzy autorzy zajmujący się problematyką zasad prawa - zob. np. G. Maroń, Zasady prawa jako sktadnik kultury prawnej, w: O. Nawrot, S. Sykuna, J. Zajadło (red.), Konwergencja czy dywergencja kultur prawnych?, Warszawa 2012, s. 223; S. Tkacz, op. cit., s. 15-16 i 237.

${ }^{6}$ Kluczowy problem to tzw. kryterium dystynkcji, czyli cecha lub zestaw cech odróżniających zasady od pozostałych norm, oraz pytanie o jego mocny lub słaby (dający podział logiczny lub wskazujący na prawidłowości) charakter - na ten temat szerzej zob. G. Maroń, Zasady prawa. Pojmowanie..., s. 23-42.

${ }^{7}$ O. Bogucki, M. Zieliński, op. cit., s. 56.

8 J. Wróblewski, Prawo obowiazujace a „ogólne zasady prawa”, „Zeszyty Naukowe Uniwersytetu Łódzkiego, Nauki Humanistyczno-Społeczne” 1965, z. 42, s. 17-38.

${ }^{9}$ Zob. G. Maroń, Zasady prawa. Pojmowanie..., s. 54-58; S. Tkacz, op. cit., s. 25-34.

${ }_{10}$ W. Lang, J. Wróblewski, Wspótczesna filozofia i teoria prawa w USA, Warszawa 1986, s. $74-90$ i $215-220$.

${ }_{11}$ T. Gizbert-Studnicki, Zasady i reguty prawne, „Państwo i Prawo” 43, 1988, z. 3, s. 16-26.

${ }^{12}$ R. Dworkin, Biorac prawa..., passim.

${ }^{13}$ R. Alexy, Teoria praw podstawowych, tłum. B. Kwiatkowska, J. Zajadło, Warszawa 2010.

${ }^{14}$ T. Gizbert-Studnicki wskazał, że stosowanie tych teorii pociaga za soba uznanie za zasadę np. „normy nakazującej ochronę dżdżownic żyjących w Parku Łazienkowskim” (idem, rec. M. Kordela, Zasady prawa. Studium teoretycznoprawne, Poznań 2012, Wydawnictwo Naukowe UAM, „Państwo i Prawo” 69, 2014, z. 3, s. 119); A. Tęcza-Paciorek, stosując je, za R. Dworkinem zaliczyła domniemanie niewinności do reguł, czyli norm o innych właściwościach niż zasada, stosowanych na zasadzie „wszystko albo nic” (eadem, Zasada domniemania niewinności w polskim procesie karnym, Warszawa 2012, s. 25-27 i 30-31). Podobnie P. Tuleja normy wyrażające prawa podstawowe w polskiej Konstytucji uznał za reguły albo zasady (idem, Normatywna treść praw 
nio monografie Mileny Koryckiej-Zirk, Marzeny Kordeli i Sławomira Tkacza, którzy zaprezentowali autorskie podejścia do problemu ${ }^{15}$. W światowej teorii prawa najczęściej przywoływana jako principles theory jest teoria Alexy'ego, przy podkreślaniu jej pochodzenia od Dworkina ${ }^{16}$; ich krytyki lub prób rozwinięcia dotyczą inne wypowiedzi na temat zasad, których autorzy, prezentując oryginalne poglądy, odnosza je do dwóch wymienionych ${ }^{17}$.

Istniejące koncepcje $\mathrm{w}$ wielu kwestiach pozostaja sobie przeciwstawne. Według Grzegorza Maronia porządkowanie norm na dwie grupy „W dużym stopniu determinują ostatecznie oceny tego, kto klasyfikację taką przeprowadza"18. Twierdzenie to dotyczy również przyjmowanej na tę okoliczność teorii. Mátyás Bódig stwierdził podobnie, że:

Istnieje pokaźna grupa teoretyków prawa, którzy czynią nadzwyczajne wysiłki, aby uzyskać sensowne rozróżnienie. Podjęto szereg prób wyjaśnienia pojęcia „zasady” w teorii prawa, ale sprawa wciąż pozostaje kontrowersyjna w teorii współczesnej. Może być to jedno z tych pojęć, którym po prostu przeznaczone jest pozostać kontrowersyjnymi ${ }^{19}$.

Opracowanie niniejsze nie jest kolejną próbą opowiedzenia się za którą́s z teorii zasad; ma na celu spojrzenie na opisany problem z zewnętrznej perspektywy i bardziej skupia uwagę na samej dyskusji niż dyskutowanej materii. W tym celu wykorzystano mało rozpoznaną w rodzimej nauce ideę „pojęć co do istoty kwestionowanych" (essentially contested concepts) ${ }^{20}$ stworzona przez Waltera Bryce'a Galliego.

jednostki w ustawach konstytucyjnych RP, Warszawa 1997, s. 77). Na tych podstawach O. Bogucki i M. Zieliński wyrażają sprzeciw wobec stosowania teorii R. Alexy'ego i R. Dworkina w polskim prawoznawstwie (eidem, op. cit., s. 60-80). Zgodnie z ustaleniami G. Maronia kryterium dystynkcji właściwe „polskiej teorii zasad prawa” należy uznać za posiadające charakter słaby, jak zaś wskazuje R. Poscher, teza o logicznym rozróżnieniu dwóch gatunków norm (kryterium mocne) jest niezbędną podstawą teorii D/A (określenie T. Gizberta-Studnickiego, rec. M. Kordela..., s. 117] na teorie R. Alexy'ego i R. Dworkina): „Gdyby zasady były tylko gatunkiem reguł, teoria zasad musiałaby szukać dla siebie nowego imienia" (tłum. własne) - R. Poscher, The principles theory. How many theories and what is their merit?, w: M. Klatt (ed.), Institutionalized Reason. The Jurisprudence of Robert Alexy, Oxford 2012, s. 220.

${ }_{15}$ M. Korycka-Zirk, Teorie zasad prawa a zasada proporcjonalności, Warszawa 2012 oraz cytowane wyżej prace M. Kordeli i S. Tkacza.

${ }^{16}$ R. Poscher, op. cit., s. 218-219; dalej jako: teorie D/A.

${ }^{17}$ M. Atienza, J. Ruiz Manero, op. cit.; H. Ávila, Theory of Legal Principles, Dordrecht 2007; A. Aarnio, Essays on the Doctrinal Study of Law, Dordrecht-Heidelberg-London-New York 2011, s. 119-124. Szerszy wykład wraz z bogatą literatura przedstawia G. Maroń, Zasady prawa. Pojmowanie..., s. 16-54.

${ }^{18}$ Ibidem, s. 59.

${ }_{19}$ M. Bódig, op. cit., s. 1.

${ }^{20}$ Dalej jako: ECC. Nie uzgodniono dotąd tłumaczenia tej nazwy na język polski. Niektóre propozycje to: „pojęcie istotnie, zasadniczo sporne” (K. Minkner, Problem polityczności jako metateoretyczne wyzwanie dla politologii, „Atheneum. Polskie Studia Politologiczne” 2014, z. 43, s. 15); „pojęcia notorycznie kontrowersyjne” (Z. E. Raskal, Paula Thagarda kryteria demarkacji, „Roczniki Filozoficzne" 62, 2014, nr 1, s. 27). W obrębie nauki prawa A. Dyrda zaproponował nazwę „pojęcia z istoty sporne” (Czy pojęcie prawa jest pojęciem z istoty spornym?, „Archiwum Filozofii Prawa i Filozofii Społecznej” 2013, nr 1, s. 54-67). 


\section{IDEA POJĘĆ CO DO ISTOTY KWESTIONOWANYCH (ECC)}

\section{Informacje ogólne}

Idea „pojęć co do istoty kwestionowanych” (essentially contested concepts - ECC) sformułowana została w pierwszej połowie $1956 \mathrm{r}$. w dwóch tekstach. Pierwszy był jej teoretycznym ujęciem, drugi zaś - wzorcowym jej wykorzystaniem na przykładzie pojęcia „sztuka”"1. Uniwersalność sformułowania umożliwia zastosowanie jej na gruncie wielu dziedzin nauki, głównie humanistycznych ${ }^{22}$ (w tym prawa ${ }^{23}$ ), a także nauk ścisłych ${ }^{24}$. Dlatego też jej wykorzystanie poprzedzają niekiedy krytyczne uwagi metodologiczne (ideę wyróżnia charakterystyczny sposób ujęcia, który to ułatwia). Rozmiary opracowania nie pozwalają wyczerpująco przytoczyć ich wszystkich, dlatego przywołane będą jedynie wybrane.

\section{Teza o istotowej kwestionowalności i jej siedem warunków}

U podstaw idei ECC leży teza o istotowej kwestionowalności ${ }^{25}$. Głosi ona, że istnieja pojęcia, wobec których nie sposób podać jednej wyraźnie sformułowanej definicji kierującej ich użyciem w dyskusjach i którą można byłoby uznać za poprawną lub przynajmniej standardową ${ }^{26}$. Różne grupy posługuja się nimi, nadając im poprzez użytek rozmaite funkcje znaczeniowe (we własnym, ograniczonym gronie mogą używać go w pełni zgodnie). Jednak nawet gdy ta różnorodność zostanie ujawniona, obstają przy twierdzeniu, że przypisywana pojęciom $\mathrm{w}$ ramach ich interpretacji funkcja jest ta, którą należy uważać za jedyna, poprawna, główną czy też najważniejszą spośród wszystkich, jakie pojęcie pełni lub może pełniće ${ }^{27}$. Wszystkie grupy posługujące się

${ }^{21}$ W. B. Gallie, Essentially contested concepts, „Proceedings of the Aristotelian Society” 56(1), 1956, s. 167-198; idem, Art as an essentially contested concept, „The Philosophical Quarterly” 6(23), 1956, s. 97-114. W. B. Gallie poświęcił jej także rozdział w monografii Philosophy and Historical Understanding, London 1964. Na określenie myśli Galliego celowo posługuję się w pracy słowem „idea”. Równie stosowne byłoby „teoria”, ale „idea” lepiej oddaje dwie możliwości jej interpretacji, o czym niżej.

${ }^{22}$ Przykładowo wymienić można: A. MacIntyre, The essential contestability of some social concepts, „Ethics” 84, 1973, s. 1-9; J. N. Gray, On the contestability of social and political concepts, „Political Theory” 3, 1977, s. 331-348; C. Swanton, On the essential contestedness of political concepts, „Ethics” 95, 1985, s. 811-827; D. Collier et al., Essentially contested concepts: debates and applications, „Journal of Political Ideologies” 3, 2006, s. 211-246; D. H. Ruben, W. B. Gallie and essentionally contested concepts, „Philosophical Papers” 39, 2010, s. 257-270.

${ }^{23}$ Przykłady: J. Waldron, Vagueness in law and language: some philosophical issues, „California Law Review” 82, 1994, s. 509-540; idem, Is the rule of law an essentially contested concept (in Florida), „Law and Philosophy” 21, 2002, s. 137-164; K. M. Ehrenberg, Law is not (best considered) an essentially contested concept, „International Journal of Law in Context” 7, 2011, s. 209232; A. Dyrda, T. Gizbert-Studnicki, Over-aggregated concepts, adjective-modifiers and argumentation, w: J. Šavelka et al. (red.), Argumentation 2013. International Conference on Alternative Methods of Argumentation in Law, Brno 2013, s. 23-40.

${ }^{24}$ Np. C. McKnight, Medicine as an essentially contested concept, „Journal of Medical Ethics” 4, 2003, s. 261-262.

${ }^{25} \mathrm{~W}$ oryginale i za nim w literaturze zagranicznej-essential contestability.

${ }^{26}$ W. B. Gallie, Essentially..., s. 168.

${ }^{27}$ Ibidem. 
danym pojęciem są w stanie podać w dyskusji między sobą rzeczowe, rzetelne, poparte dowodami i przekonujace argumenty na korzyść własnego stanowiska. Ich spory sa „,autentyczne” (genuine) ${ }^{28} \mathrm{w}$ tym znaczeniu, że nie polegaja na wzajemnym niezrozumieniu lub innego rodzaju błędzie którejś ze stron. O „słuszności” żadnej z propozycji nie można jednak rozstrzygnąć za pomocą padających w nich argumentów ${ }^{29}$.

Tezę główną rozwija siedem tez szczegółowych dotyczących cech składowych pojęcia, nazwanych przez Galliego „warunkami” (conditions) ${ }^{30}$. Tworza niejednolitą grupę - są właściwościami zjawisk związanych z danym ECC, pochodzacymi z różnych kategorii (warunki II-IV dotyczą jego desygnatów ${ }^{31}$, I - sposobu użycia, a V-VII - sporu). Występują między nimi związki treściowe i logiczne. Prezentują się następująco:

I. Ocenne użycie ECC. Nie jest ono terminem deskryptywnym, którego prawidłowe użycie zależy od stwierdzenia jakichś właściwości desygnatu, choć za takie może na pozór uchodzić. Dlatego użycie pojęcia ECC do oznaczenia jakiegoś bytu nie prowadzi do skonstruowania zdania stwierdzającego fakt, ale wyrażającego ocenę, z reguły dodatnią ${ }^{32}$. Jak wspomniałem, paradygmatycznym przykładem analizowanym przez autora koncepcji było pojęcie sztuki (i co za tym idzie, dzieła sztuki ${ }^{33}$ ). Nazwanie tak czegokolwiek, nawet z wymienieniem stosownych właściwości, należy poczytywać za podkreślenie osiągnięcia, które nazywamy.

II. Wewnętrzna złożoność desygnatu. Jego desygnaty składają się z wielu opisywalnych (podatnych na ocenę) z osobna części. Ocenne posłużenie się ECC dotyczy jednak całości ${ }^{34}$.

III. Opisywalność na wiele sposobów. Sensowny opis ECC musi zawierać odniesienia do jego poszczególnych części składowych i właściwości, można jednak przy tym opisywać je i wartościować w dowolnej kolejności i proporcjach. In abstracto wszystkie mogą współistnieć, nawet jeśli przeczą sobie wzajemnie $^{35}$. Nie można podać metody wartościującej je względem siebie, która pozwalałby rozróżniać je np. pod względem prawidłowości. Gallie podpowiada, że innym sposobem ujęcia warunku III jest stwierdzenie, że ECC jest „pierwotnie narażone na niejednoznaczność”. Warunki II i III są najściślej powiązane, zazwyczaj wystapienie jednego oznacza także wystapienie drugiego.

IV. Otwartość denotacji. Desygnaty ECC moga się zasadniczo zmieniać z upływem czasu lub występować w innej niż dotychczas znana postaci,

\footnotetext{
28 Ibidem, s. 169.

${ }^{29}$ Ibidem, s. $168-169$.

30 Ibidem, s. 170.

31 Pojęciami „desygnaty” i „denotacja” posługuję się w pracy za T. Kotarbińskim (Elementy teorii poznania, logiki formalnej $i$ metodologii nauk, Warszawa 1986, s. 24-25).

${ }^{32}$ W. B. Gallie zilustrował to zjawisko na dwóch przykładach - „mistrzostwa” (Essentially..., s. 171) i „sztuki” (Art as an..., s. 111). Określając występ sportowy mianem „mistrzowskiego”, jak również nazywając czyjeś dzieło „dziełem sztuki”, wyraża się wobec niego uznanie i aprobatę.

${ }^{33} \mathrm{~W}$ Art as an... Gallie posługuje się nimi wymiennie, analizując problem dyskusji nad taka teorią sztuki, która dawałaby zestaw kryteriów pozwalających bezbłędnie charakteryzować byty jako dzieła sztuki (passim).

${ }^{34}$ Ibidem.

35 Ibidem, s. 172; idem, Art as an..., s. 112-113.
} 
czego z góry nie można przewidzieć. Z tego względu nie można mieć pewności, że posłużenie się ECC w jakiś sposób będzie w przyszłości również prawidłowe i że byt tak nazwany zawsze będzie częścią denotacji używanego pojęcia ${ }^{36}$.

Gallie wskazał, że powyższe warunki to najważniejsze, jakie każde ECC musi spełniać ${ }^{37}$. Razem nie wyjaśniają jednak, co znaczy, że pojęcie rzeczywiście jest istotnie kwestionowane ${ }^{38}$, co tłumaczy warunek $\mathrm{V}$.

V. Posługiwanie się ECC w charakterze zarazem zaczepnym i obronnym. Skorzystanie z ECC oznacza wiedzę użytkownika o tym, że jego sposób użycia będzie kontestowany przez innych dyskutantów oraz że w związku z tym wymaga obrony i uzasadnienia.

Stan istotowej kwestionowalności powstaje po spełnieniu warunków I-IV, natomiast pojęcie można uznać za ECC dopiero po wystapieniu także warun$\mathrm{ku}$ V, co jest do takiej konstatacji niezbędne ${ }^{39}$. Tym samym Gallie wprowadza implicite rozróżnienie między stanem „kwestionowalności” i „kwestionowania”, które sprecyzowano później w literaturze przedmiotu ${ }^{40}$. Różnica między pojęciem, które spełnia warunki I-IV, a pojęciem, które spełnia warunki I-V, polega na tym, czy spór jest in spe, czy już trwa. Autor dodał jednak, że nawet stwierdzenie wystapienia wszystkich pięciu warunków nie pozwala przekonać się, czy analizujemy przypadek rzeczywistego ECC będącego jednym pojęciem, czy może mamy do czynienia jedynie $\mathrm{z}$,terminologicznym bałaganem” ${ }^{41}$. Dlatego sformułował dwa dodatkowe warunki, które pozwalają takie przypadki odróżnić.

VI. Oparcie na pierwowzorze. Każde ECC pochodzi od wspólnego punktu oparcia, pierwowzoru, którego znaczenie uznają wszyscy dyskutanci. Ów pierwowzór to „cenione osiagnięcie” (valued achievement) ${ }^{42}$, poważane przez wszystkich dyskutantów, lub zbiór tradycji posiadajacych wspólny element. Jest to warunek „minimum zgody”, który zapewnia spójność dyskusji i pozwala rozpoznać, że dotyczy ona nadal tego samego pojęcia.

Według komentatorów tak wyznaczone granice mogą nadal obejmować pojęcia bardzo zbliżone, ale różne. W związku z tym zaproponowano, by przed przystapieniem do analizy danego ECC dokonać jego „rozłączenia” (disaggregation $)^{43}$ przez odrzucenie wszystkich związanych z nim, ale odrębnych elementów, które niekiedy mylnie uważa się za przejawy jego samego. Operacja może nastręczać trudności, szczególnie w świetle warunku II, należy jednak kontynuować ją tak długo, aż zyska się pewność co do mówienia o desygnatach jednego tylko pojęcia.

${ }^{36}$ Alternatywie można powiedzieć, że ECC sa „uporczywie niekonkretne” (persistently vague) - W. B. Gallie, Essentially..., s. 172.

37 Ibidem.

38 Ibidem, s. 172 i 175 .

39 Ibidem.

${ }^{40} \mathrm{Na}$ różnicę między contestable i contested uwagę zwrócili D. Collier et al., op. cit., s. 214.

${ }^{41}$ Nazywa tę sytuację conteptual confusion (Essentially..., s. 168), co przypomina przytoczona we wstępie wypowiedź M. Zielińskiego o „chaosie terminologicznym”.

${ }^{42}$ W. B. Gallie, Essentially..., s. 171.

${ }^{43}$ Pojęcie wprowadził D. Collier i jego współpracownicy. Zob. D. Collier et al., op. cit., s. 217. K. M. Ehrenberg uważa, że niemożność dalszego rozłączenia pojęcia to jeden z argumentów za dokonaniem jego analizy z pomocą idei ECC - idem, op. cit., s. 215. 
VII. Rozwój wskutek używania. Powinny istnieć podstawy do przewidywania, że dalsze czynienie użytku z ECC doprowadzi do jego rozwoju w optymalny sposób. Ponadto, mimo dyskusyjności sposobu użycia, wykorzystanie ECC powinno jawić się jako pożyteczne. Przez rozwój pojęcia i otaczającej go dyskusji Gallie rozumiał konstruowanie przez dyskutantów coraz lepszych i bardziej wyrafinowanych argumentów, które same w sobie są wartościa i pozwalają lepiej zrozumieć jego naturę. Warunek VII stawia zatem potrzebę uzasadnienia posługiwania się ECC w perspektywie globalnej.

W literaturze ECC zadano pytanie, czy dla uznania pojęcia za ECC konieczne jest spełnienie warunków kumulatywnie. Gallie uważał, że niezbędnymi elementami „formalnej definicji” są warunki I-V ${ }^{44}$. Wielu komentatorów stwierdziło, że jest to podejście zbyt restrykcyjne, sugerując, że problem znika, jeśli zmieni się interpretację na temat tego, czym są warunki ${ }^{45}$. Przeciwnicy rozluźnienia rygorów wskazywali jednak na brak opamiętania w mnożeniu ECC $^{46}$, któremu ono sprzyja. Podnoszono, że rzetelne stosowanie idei ECC możliwe jest tylko przy konsekwentnym trzymaniu się wszystkich siedmiu warunków ${ }^{47}$.

\section{Interpretacje idei ECC}

Tezy idei ECC można interpretować rozmaicie. Gallie nazwał ja „hipoteza eksplikacyjną" (explanatory hypothesis) ${ }^{48}$, postulującą istnienie przynależnych do klasy ECC pojęć i wyjaśniającą właściwości dotyczących ich dyskusji, ze wszystkimi wskazanymi wyżej konsekwencjami. W tym ujęciu (nazywam je „ontologicznym”) warunki pełnią rolę przesłanek, które pozwalają stwierdzić konsekwencje opisane tezą o istotowej kwestionowalności. Ta zaś ma kategoryczną wymowę - dla rozpoznanego ECC jest stanem nieuniknionym i nieusuwalnym. Interpretacja jest atrakcyjna, w formie warunków dostarcza bowiem wytłumaczenia jego przyczyn i usprawiedliwia zaprzestanie dążeń do powszechnej zgody. Daje też w formie warunków instrukcję, jak znajdować ECC, mogąc pełnić funkcję „testu”.

Sformułowano wobec niej szereg zarzutów. Przede wszystkim wskazano, że już sama teza o istotowej kwestionowalności nie jest dostatecznie dobrze udowodniona ${ }^{49}$. Wyrażono obawę, że prowadzić może do nihilizmu i „pojęciowego relatywizmu” ${ }^{50}$, podniesiono też, że związki między warunkami nie sa wystarczająco jasne oraz że idea w tej postaci sama może być ECC ${ }^{51}$. Szczegól-

${ }^{44}$ Autor wskazał jednak, że bez warunków VI i VII można co najwyżej rozpoznać pojęcie, ale nie można uzyskać pewności, czy dalszy jego użytek jest sensowny (Essentially..., s. 180).

${ }^{45}$ D. Collier et al., op. cit., s. 215. Autorzy należą do zwolenników posługiwania się ideą ECC w wersji analitycznej (zob. niżej).

46 J. Waldron, op. cit., s. 149.

${ }^{47}$ L. Green, The political content of legal theory, „Philosophy of the Social Sciences” 17, 1987, s. 17 (cyt. za: K. M. Ehrenberg, op. cit., s. 210).

${ }^{48}$ W. B. Gallie, Essentially..., s. 168.

49 C. Swanton, op. cit., s. 826-827.

50 J. N. Gray, op. cit., s. 343.

${ }^{51}$ Zob. K. M. Ehrenberg, op. cit., s. 213, przyp. 9. 
nie przekonujący jest ostatni argument, ponieważ w jego świetle staje się ona „samospełniająca przepowiednią”.

Druga znana interpretacja (,analityczna”) jest łagodniejsza w wymowie; zgodnie z nią warunki podane przez Galliego składają się na metodologiczny schemat, z którego można i niekiedy warto skorzystać do zbadania pojęć wykazujących prima facie właściwości odpowiadające sytuacji istotowego kwestionowania. Jej zwolennicy nie twierdza, że istotowa kwestionowalność to immanentna cecha ECC ani też że stan istotowego kwestionowania i jego konsekwencje sa nieusuwalne. W tej wersji nie jest to immanentna cecha klasy pojęć, a raczej faktyczna właściwość dotycząca niektórych, o stopniowalnym natężeniu ${ }^{52}$. Zbadanie pojęcia metodą ECC oznacza jedynie próbę ustalenia, czy główna teza o istotowej kwestionalności go dotyczy, a jeśli tak - dlaczego; warunki zaś pełnią funkcję mierników - im więcej pojęcie ich spełnia, tym zasadniejsze jest uznanie go za $\mathrm{ECC}^{53}$. Tak pojmowana idea pozwala uniknąć kontrowersyjnych wniosków, ale nie dostarcza tak wyraźnego i eleganckiego wytłumaczenia stanu istotowego kwestionowania, jak interpretacja ontologiczna. Osłabia też siłę niektórych argumentów w dyskusjach dotyczących pojęcia (np. za rezygnacją z jego użytku).

Niezależnie od przyjętego stanowiska do badania „kandydata” na ECC najlepiej wykorzystać wszystkie warunki. Zatem im większa ich liczba, tym analiza będzie owocniejsza, a ewentualne przyjęcie wniosków interpretacji ontologicznej będzie bardziej uzasadnione.

\section{IDEA ECC A POJĘCIE ZASAD PRAWA}

\section{Rozłączenie pojęcia zasad prawa i jego istotowa kwestionowalność}

Zgodnie z uwagami poczynionymi powyżej, pierwszym krokiem w badaniu pojęcia zasad prawa za pomocą idei ECC powinno być jego właściwe „rozłączenie". W tej materii pozostaje odwołać się do wspomnianych ustaleń szkoły poznańskiej i zaznaczyć, że analizie podlegać będa „zasady w ujęciu dyrektywalnym", stanowiące normy obowiąującego prawa. Opisany we wstępie stan dotyczącej ich dyskusji teoretycznej można uznać za wypełniający znamiona tezy o istotowej kwestionowalności prima facie na tyle, aby poddać pojęcie badaniu przez warunki ${ }^{54}$. Żadnej ze wspomnianych teorii (,,koncepcji polskiej”, teorii D/A ani którejś z powstałych w ostatnich latach ${ }^{55}$ ) nie uznano powszechnie za je-

52 Ibidem, s. 214-215.

${ }^{53}$ K. M. Ehrenberg, op. cit., s. 214. Można powiedzieć, że zależnie od przyjętej metody badań warunki odpowiadają na pytanie, „czy” albo „dlaczego”. Na pierwsze - gdy podejmuje się próbe identyfikacji pojęcia jako ECC, na drugie - przy uzasadnieniu odpowiedzi twierdzącej.

${ }^{54}$ Por. ibidem, s. 210-211. Autor wskazuje, że nawet gdy pojęcie warunki spełnia, jest to tylko „punkt wyjścia” do uznania go za ECC, decydować powinna o tym bowiem przede wszystkim przydatność takiej konstatacji.

55 Ramy opracowania nie pozwalają na wyczerpującą analizę poprzez warunki ECC wszyst- 
dyną poprawna, jeśli chodzi o sprecyzowanie właściwości zasad prawa. Każda ma swoich zwolenników i każda jest wyczerpująco uargumentowanym sposobem posłużenia się pojęciem. Nie sposób wskazać metody pozwalającej rozstrzygająco wskazać jedną z nich jako „słuszną” bardziej niż pozostałe.

\section{2. „Zasady prawa" w świetle siedmiu warunków}

I. Ocenny sposób użycia. Wyróżnienie normy prawa spośród ogółu norm jako „zasady” oznacza uznanie jej za donioślejszą od pozostałych. W „koncepcji polskiej” określa się tak normy obejmujące hipotezą większy zakres sytuacji, zawierające bogatszą treść, ukierunkowujące wykładnię pozostałych norm, mające znaczaccy wpływ na stanowienie prawa, o najwyższej pozycji w hierarchii danego systemu. Na podstawie teorii D/A, kładacych nacisk na strukturę norm, dopuszczalne jest uznanie za zasady także norm mniej doniosłych ${ }^{56}$, stworzono je jednak dla analizy norm konstytucyjnych (Alexy) lub by podkreślić, że prawo zawiera także - doniosłe z istoty - standardy moralne (Dworkin). Nazwanie normy „zasadą oznacza jej pozytywne wartościowanie jako cennego elementu dorobku myśli prawniczej i szerzej - kultury we wszystkich tych teoriach. Zakodowane w prawie obowiazującym zasady stanowiące podstawy ustroju państwa, zasady podatkowe ${ }^{57}$ czy zasady procesu karnego ${ }^{58}$ to efekty długotrwałych i dramatycznych walk politycznych, a najczęściej również cenne osiagnięcia intelektualne, a nawet cywilizacyjne ${ }^{59}$.

II. Wewnętrzna złożoność. Wewnętrzna złożoność zasad podkreślana jest w obu koncepcjach. „Teoria polska” opuszcza pojmowanie zasad jako agregatów funkcjonalnie związanych ze sobą norm ${ }^{60}$, a także jako norm, z których wynikają inne, bardziej szczegółowe, uznawane za „przejawy” zasady głównej61. W analogiczny sposób cechę tę opisuja teorie D/A. Zasady, konkretyzowane w stosowaniu przez wyważanie, przekształcane są w odpowiednie reguły, które zależą od unikalnych dla danego przypadku

kich obecnych w obrębie polskiej teorii prawa koncepcji. Dlatego poniżej odnoszę je głównie do dwóch głównych, tj. koncepcji „tradycyjnej” oraz teorii D/A.

${ }^{56}$ Por. przykład „zasady ochrony dżdżownic w Parku Łazienkowskim” T. Gizbert-Studnickiego przytoczony w przypisie 14 powyżej.

${ }^{57}$ Zob. np. W. Nykiel, Zasady podatkowe, w: B. Brzeziński (red.), Prawo podatkowe. Teoria. Instytucje. Funkcjonowanie, Toruń 2009, s. 13-20.

${ }_{58}$ M. Cieślak, Polska procedura karna. Podstawowe założenia teoretyczne, Kraków 2011, s. 158.

${ }^{59} \mathrm{Za}$ takie uważa się np. zasady podatkowe sformułowane przez A. Smitha czy zasady prawa karnego zaproponowane przez C. Beccarię. Uwagi te dotyczą przede wszystkim „zasad opisowych", jako idei stanowiących źródło wyrażeń dyrektywalnych. M. Cieślak, rozróżniając zasady „abstrakcyjne" i „konkretne”, wskazał, jak tego rodzaju zasady-idee łączą się z zasadami-normami (idem, op. cit., s. 158-168).

${ }^{60}$ M. Żbikowska, Status ontologiczny zasad procesu karnego, „Państwo i Prawo” 71, 2016, z. 3 , s. $60-63$.

${ }^{61}$ J. Wróblewski, op. cit., s. 25-26. Przykładu takiej zasady dostarcza zasada demokratycznego państwa prawnego - na ten temat zob. S. Wronkowska, Charakter prawny klauzuli demokratycznego państwa prawnego (art. 2 Konstytucji Rzeczypospolitej Polskiej), w: eadem, Zasada demokratycznego państwa prawnego w Konstytucji RP, Warszawa 2006, s. 112-119. 
okoliczności prawnych i faktycznych. Z zasadami ugruntowanymi i doniosłymi wiążą się w doktrynie i orzecznictwie (w optyce tych teorii) „reguły” dla nich typowe, z których „składają się” one jako poszczególne jednostki normatywne ${ }^{62}$. W myśl tych teorii zasady złożone są również pod względem formalnym ${ }^{63}$.

III. Możliwość opisu na wiele sposobów. Powyższy warunek ekstensja pojęcia zasad prawa spełnia wyjątkowo wyraźnie. Świadczy o tym mnogość różnorodnych propozycji, z których każda za „kryterium dystynkcji” pozwalające znaleźć zasady wskazuje inną ich cechę ${ }^{64}$. Poszczególne teorie opierają się na jednej z nich lub kilku wybranych, różnie opisując charakter samego kryterium jako „słaby” lub „mocny”; niektóre cechy zasad wskazywane w teoriach pojawiają się także w innych, które w odmienny sposób kładą na nie nacisk w opisie. Podaje się różnorodne propozycje wewnętrznych podziałów klasy norm uznanych za zasady ${ }^{65}$, a także ich katalogi dotyczace tej samej materii ${ }^{6}$.

IV. Otwartość. Każda ze znanych teorii zasad prawa uznaje fakt, że ich treść ani katalog nie są niezmienne. Cecha ta jest pochodna prawa jako takiego, które siła rzeczy podlega zmianom z upływem czasu; w ten sposób nazwanie normy „zasadą” może okazać się w przyszłości nieaktualne ze względu na decyzje prawodawcy. Tych zaś nie można przewidzieć w dłuższej perspektywie, ponieważ treść porządku prawnego wyznaczają czynniki pozaprawne. „Otwartość” zasad jest silniej jeszcze akcentowana przez teorie D/A, w których ich katalog, treść i stosowanie zależy od zmiennej „moralności politycznej społeczeństwa" (Dworkin) lub doboru wyważanych wartości oraz okoliczności przypadku (Alexy). Wyczerpująco opisuje proces ewolucji kata-

${ }^{62}$ Trybunał Konstytucyjny w swoim orzecznictwie np. z zasada zaufania do państwa i prawa wiąże m.in. reguły zakazu retroakcji prawa w jego stanowieniu i wykładni (np. orzeczenie z 22 czerwca 1993 r., K 1/93, OTK ZU 1993, nr 2, poz. 25; wyrok z 12 kwietnia 2000 r., K 8/98, OTK ZU 2000, nr 3, poz. 87), nakazu rozstrzygania wątpliwości na korzyść obywatela (np. uchwała z 11 stycznia 1995 r., W 11/94, OTK ZU 1995, nr 1, poz. 17), czy „zakazu zaskakiwania” obywatela nowym ustawodawstwem wprowadzanym bez stosownego okresu przejściowego (orzeczenie z 14 grudnia $1993 \mathrm{r}$., K 8/93, OTK ZU 1993, nr 2, poz. 43; wyrok z 5 listopada 1997 r., K 22/97, OTK ZU 1997, nr 3-4, poz. 41).

${ }^{63}$ Fakt ten uwidacznia się na dwa sposoby - pierwszy w przypadku zasad sprawiających „wrażenie absolutności”, które składają się w rzeczywistości z zasady stanowiącej ważone wobec innych zasad lingwistyczne kryterium oceny oraz reguły stosowanej bez stopniowania, jeśli kryterium to przeważy (R. Alexy za przykład podaje art. 1 ust. 1 zd. pierwsze niemieckiej konstytucji: „Godność człowieka jest nienaruszalna”. Szerzej - idem, Teoria..., s. 92-95). Ponadto w budowie zasady można wyróżnić „obiekt optymalizacji” oraz „nakaz optymalizacji”, jeśli zaistnieje taka potrzeba (idem, On the Structure..., s. 300-301).

${ }^{64}$ Np. R. Alexy wskazuje osiem ich przykładów, Teoria..., s. 75-76.

${ }^{65}$ Np. R. Dworkin zaproponował wewnętrzny podział zasad na „zasady sensu stricto” i „polityki”, nie twierdząc jednak, by charakteryzowały się one różnymi właściwościami (Biorac prawa..., s. 56-58). Dlatego też rozróżnienie to odrzucił R. Alexy (Teoria..., s. 95-96). M. Atienza i J. Ruiz Manero na jego podstawie stworzyli jednak czwórpodział norm, przypisujac ,zasadom sensu stricto" i „politykom” odmienny sposób stosowania i działanie w przypadku kolizji (eidem, op. cit. s. 7-25).

${ }^{66}$ Por. zebrane przez P. Wilińskiego przykłady 15 katalogów zasad procesu karnego, w których liczba zasad waha się od 6 do 31 - idem, Katalog zasad procesu karnego, w: P. Hofmański (red.), op. cit., s. 126-132. Podobną sytuację ilustruje m.in. w dogmatyce prawa konstytucyjnego S. Tkacz (op. cit., s. 136-141). 
logu zasad teoria Tkacza ${ }^{67}$; można wskazać przykłady doniosłych w polskim porządku prawnym norm uznawanych za zasady o rodowodzie nie dłuższym niż około 40 lat ${ }^{68}$.

V. Równoczesność zaczepnego i obronnego posłużenia się pojęciem. Świadome posłużenie się pojęciem zasad prawa oznacza opowiedzenie się za którąś z istniejących teorii albo stworzenie własnej, czego dowody, prócz prac teoretyków wprost forsujących daną koncepcję, znaleźć można $\mathrm{w}$ monografiach $\mathrm{z}$ dyscyplin szczegółowych ${ }^{69}$. Warunek $\mathrm{V}$ nie wymaga, aby każdy uczestnik dyskusji znał wszystkie inne stanowiska i na ich tle prezentował własne. Stan taki byłby pożądany, ale nie jest osiąalny. Niewątpliwie jednak im dokładniejsze uargumentowanie wyboru, tym większa szansa na poszerzenie grona zwolenników preferowanej koncepcji.

VI. Oparcie na pierwowzorze. W zagranicznej teorii prawa zagadnienie zasad wyrasta z krytyki paradygmatu pozytywistycznego ${ }^{70}$, która leży u podstaw większości koncepcji i spaja dotycząca ich dyskusję. Zasady warunek VI spełniają więc przez oparcie się na ,zbiorze tradycji”. Pierwsza chronologicznie „polska koncepcja” powstała niezależnie od tej dyskusji i opierała się na założeniach pozytywistycznych. W tym przypadku za „tradycję" można przyjać przekonanie o nadzwyczajnej doniosłości norm stanowiących zasady, które do dzisiaj rozpowszechnione jest w polskim prawoznawstwie i stanowi źródło polemiki ze zwolennikami teorii D/A. Włączenie ich założeń w rodzimy dyskurs spowodowało, że obecne są w nim obie.

VII. Rozwój wskutek używania. Niezależnie od tego, czy za punkt początkowy dyskusji dotyczącej zasad przyjmie się opublikowanie wspominanych prac Essera, Wróblewskiego czy Dworkina, nie ulega wątpliwości, że ich myśli rozwinięto w szereg owocnych i bogato uargumentowanych koncepcji stanowiących wartość dodaną teorii prawa oraz dyscyplin szczegółowych.

${ }^{67} \mathrm{~W}$ tej teorii o uznaniu normy za zasadę decyduje zgodne przekonanie o jej „zasadniczości” uzgadniane w dyskursie „trzech aktorów”, którymi są doktryna, orzecznictwo i ustawodawca (S. Tkacz, op. cit., s. 431-433).

${ }_{68}$ Zob. J. Nowacki, O uzasadnieniu zasady zaufania $w$ orzecznictwie Trybunatu Konstytucyjnego, w: C. Martysz, A. Matan, Z. Tobor (red.), Zasady prawa. Materiaty konferencyjne, Bydgoszcz-Katowice 2007, s. 147-182. Autor wskazuje, że zasada zaufania do państwa i stanowionego przez nią prawa stanowi ideologiczny postulat, który do rangi „zasady prawa” podniósł w swoim orzecznictwie TK, począwszy od orzeczenia K 1/88 z 30 listopada 1988 r. (OTK 1988, poz. 6).

${ }^{69}$ Zob. np. A. Mariański, Rozstrzyganie watpliwości na korzyść podatnika. Zasada prawa podatkowego, Warszawa 2009, s. 39-44; J. Kosowski, Zasada informacji prawnej w polskim procesie karnym $w$ świetle art. 16 k.p.k., Warszawa 2011, s. 19-23; M. Żbikowska, Zasada lojalności w procesie karnym (odniesiona do pokrzywdzonego), Toruń 2015, s. 13-37.

${ }^{70}$ R. Poscher wskazuje, że krytyka pozytywistycznego modelu stosowania prawa była już wspomniana praca J. Essera z 1956 r. (op. cit., s. 221); wspomniany artykuł R. Dworkina z 1967 r. zawiera słynne zdanie: „Mam zamiar przeprowadzić frontalny atak na pozytywizm, używając jako tarczy strzelniczej wersji H. L. A. Harta w momencie, gdy będzie potrzebny cel bardziej konkretny” (The Model..., s. 22, tłum. T. Kowalski). Koncepcja R. Alexy’ego to część jego „niepozytywistycznej filozofii prawa”, o której szerzej: M. Dybowski, Robert Alexy - niepozytywistyczna filozofia prawa, w: J. Zajadło (red.), Przyszłość dziedzictwa. Robert Alexy, Ralf Dreier, Jürgen Habermas, Otfried Höffe, Arthur Kaufmann, Niklas Luhmann, Ota Weinberger. Portrety filozofów prawa, Gdańsk 2008, s. 29-60. 
Wielość opracowań opartych na rozmaitych poglądach na naturę prawa (np. w kontekście sporu pozytywizm-niepozytywizm) pozwala na korzystanie z nich w ramach prac odwołujących się do poglądów właściwych różnym wizjom prawa. W toku dyskusji rozwijano także badania dotyczące innych zagadnień teoretycznych ${ }^{71}$.

\section{WNIOSKI}

W świetle powyższych, siłą rzeczy podstawowych, ustaleń pojęcie „zasady prawa" można uznać za ECC. W kontekście nakreślonych wyżej możliwości interpretacji idei wypada stwierdzić, że przyjęcie w tym miejscu wniosków wskazywanych przez interpretację ontologiczną byłoby przedwczesne i wymagałoby znacznie bogatszego uzasadnienia. Z praktycznego zastosowania idei ECC w wersji analitycznej według zaprezentowanego wzoru można jednak wyciagnacć pewne wnioski.

Opisany warunkiem I ocenny sposób użycia ECC w połączeniu z właściwościami jego denotacji wskazywanymi warunkami II-IV pozwala zrozumieć, dlaczego trudno ustalić „,wspólna wersję” teorii zasad. Argumentacja w tej sferze polega bowiem na przekonywaniu zamiast udowadnianiu. Abstrahując od pytania o ostateczność istotowej kwestionowalności, sama możliwość uznania jej za fakt dotyczacy „zasad prawa” sugeruje, jaką naturę powinny mieć przyszłe argumenty przemawiajace za konkretną propozycją „teorii wszystkiego” dla zasad (a także dla koncepcji przyjmowanych w konkretnych przedsięwzięciach badawczych). Powinny one uwydatniać przede wszystkim korzyści płynace z proponowanych wersji, ich możliwe zastosowania i potencjał eksplikacyjny. Nie odrzucając prób udzielania odpowiedzi na pytania najpoważniejsze, jak np. o to, „czym zasady w swej istocie są, można przyjaćc, że tego rodzaju argumenty mają mniejszą szansę doprowadzić do wiążących rozstrzygnięć, czy choćby zjednać podnoszacemu je nowych zwolenników ${ }^{72}$. Jeśli zaś przyjmowana teoria zasad ma charakter konwencjonalny, to i im należy go przypisaćc ${ }^{73}$, i one również powinny mieć wymowę nakreśloną wyżej. Wagę właściwego uzasadnienia proponowanego sposobu użycia uwypukla warunek $\mathrm{V}$.

Powyższe wnioski można podkreślić odwołaniem do filozofii Nelsona Goodmana. Istnienie różnych, niezgodnych ze sobą teorii zasad prawa to przykład istnienia różnych, niezgodnych ze soba, „wersji świata”, które według poglądów tego autora tworzymy, opisując otaczającą nas rzeczywistość. Goodman odrzucił możliwość uznania jednej z nich za lepszą od pozostałych przez po-

${ }^{71}$ Oprócz stanowiącej przedmiot dyskusji Harta i Dworkina tezy o separacji prawa i moralności można wymienić także zajmującą ich kwestię dopuszczalnej w stosowaniu prawa dyskrecjonalności, spór kognitywizm-akognitywizm w metaetyce w kontekście związu zasad i wartości (M. Kordela, op. cit., s. 124-134), czy teorię argumentacji prawniczej (R. Alexy, Teoria..., s. 410429). Więcej przykładów wraz z literatura podaje np. R. Poscher, op. cit.

72 Por. S. Tkacz, op. cit., s. 431: „Uważam, że poszukiwanie odpowiedzi na pytanie, czym sa "zasady prawa", nie może doprowadzić do zadowalających rezultatów".

${ }^{73}$ M. Żbikowska, Status..., s. 58-60. 
równanie z obiektywnym wzorcem, co koresponduje z tezami idei ECC. Wskazał, że „światy” nie istnieją bez „wersji”, tj. nie da się dotrzeć do „świata bazowego" bez opisu. Każdy „świat” jest jakimś opisem i odwrotnie ${ }^{74}$. Dlatego też

zamiast [...] pytać o prawdę bądź fałsz obrazów, należałoby raczej zważać na dobro bądź zło teorii; prawdziwość bowiem praw teorii jest tylko szczególnym rysem [...] często [...] nie tak istotnym jak perswazyjność, zwartość i ogólność, informacyjność i organizująca moc całego systemu $^{75}$.

Na przykładzie „świata” sprowadzającego się jedynie do prostokąta, w którym punkty opisać jako składające się z przecinających się pionowych i poziomych linii albo wyrwy w przestrzeni, Goodman pokazuje, że także oceniana w kategoriach prawdy i fałszu treść teorii-wersji to kwestia konwencji, i sugeruje, aby zamiast o tym, „czym sa punkty”, dyskutować nad ich struktura ${ }^{76}$. Konwencje o faktach nie kreują faktów, ale podobieństwa i różnice struktur przyjmowanych konwencji do sfery faktów należą. Można je porównywać i oceniać, która lepiej nadaje się do stawianych celów ${ }^{77}$. Innymi słowy:

w przypadku kategoryzacji pożądane jest nie uzasadnienie prawdziwości, lecz tego, jak wiele potrafi ona dokonać. Nie bawiąc się w subtelności, rzec można, że są to rzeczy, jakich nie można dowieść, ale trzeba umieć sprzedać ${ }^{78}$.

mgr Szymon Obuchowski

Uniwersytet Gdański

sz.obuchowski@prawo.ug.edu.pl

\section{THE NOTION OF THE 'PRINCIPLES OF LAW' IN THE LIGHT \\ OF THE IDEA OF 'ESSENTIALLY CONTESTED CONCEPTS'}

\section{Summary}

Despite many studies on the theoretical properties of the 'principles of law' none of the theories proposed has been recognised as a leading or more accurate one than others. The paper is an attempt to examine the reasons for this, by examining the notion of the 'principles of law' in the light of the idea of 'essentially contested concepts' (ECC), introduced by Walter B. Gallie. This concept is little known in Polish legal scholarship. Depending on the views regarding its nature, the 'essentially contested concept' may be seen as an analytic framework pointing at its attributes and the attributes of a dispute about it, or as an ontological 'explanatory hypothesis' attributing to certain concepts a natural impossibility of reaching an agreement as to the proper use of these concepts. Regardless of the adopted view, the analysis of the 'principles of law' as an essentially contested concept provides a possibility to cast a glance at the discussion concerning their theoretical nature from an 'external', or independent point of view. This in turn allows for a thesis that the argumentation for a specific way of use of the concept of 'principles' should, to a greater extent than it is done by statements concerning the true nature of 'principles', which are the conventional by nature, advocate the suitability and utility of the theories proposed.

\footnotetext{
${ }^{74}$ N. Goodman, Jak tworzymy świat, tłum. M. Szczubiałka, Warszawa 1997, s. 10-14.

${ }^{75}$ Ibidem, s. 29.

${ }^{76}$ Ibidem, s. 129-137.

${ }^{77}$ Ibidem, s. 137-140.

${ }^{78}$ Ibidem, s. 154.
} 
